\title{
Risk of venous thromboembolism in users of contraception and menopausal hormone therapy during the COVID-19 pandemic
}

\author{
(iD)Andréa Larissa Ribeiro Pires ${ }^{1}$ \\ (D) José Gomes Batista ${ }^{1}$ \\ (iD) José Mendes Aldrighi',3 \\ (Dineu Francisco Delfino Silva Massaia² \\ (iD) Diego Medeiros Delgado ${ }^{1}$ \\ (iD) Edson Santos Ferreira-Filho ${ }^{4}$ \\ (iD) José Maria Soares-Junior ${ }^{4}$
}

1. Departamento de Obstetrícia e Ginecologia - Centro de Ciências Médicas - Universidade Federal da Paraíba (UFPB), João Pessoa, PB, Brasil. 2. Faculdade de Ciências Médicas da Santa Casa de São Paulo, São Paulo, SP, Brasil.

3. Faculdade de Saúde Pública da Universidade de São Paulo, São Paulo, SP, Brasil. 4. Hospital das Clínicas HCFMUSP, Faculdade de Medicina, Universidade de São Paulo, São Paulo, SP, Brasil.

http://dx.doi.org/10.1590/1806-9282.66.S2.22

\section{SUMMARY}

OBJECTIVES: The outbreak of coronavirus disease (COVID-19) is a public health emergency of international concern. Inflammatory changes are part of COVID-19 pathophysiology and this might generate a higher thromboembolic risk in patients using combined hormonal contraception and menopausal hormone therapy. We aimed to discuss the main aspects related to this issue and propose management strategies for women affected by COVID-19.

METHODS: This narrative review collected information from several articles published since the beginning of the outbreak of the new coronavirus disease about the pathophysiology, stage of the disease, the occurrence of thrombotic events, and the risk of thromboembolism in users of contraception and hormonal therapy.

RESULTS: This article consolidates clinical parameters about the risk of venous thromboembolism in users of contraception and menopausal hormone therapy emphasizing the probable increase of that risk in women with suspected or confirmed COVID-19 and bringing safer recommendations.

CONCLUSIONS: In this scenario, apart from the fundamental orientations of preventive measures, like social isolation and hygiene, it is important that all female health professionals have knowledge of the new rules and adopt safety measures, especially on the prescription of hormonal therapy and contraception.

KEYWORDS: Contraception. Hormone Replacement Therapy. Coronavirus Infections. Betacoronavirus. Venous Thromboembolism/ prevention \& control.

\section{INTRODUCTION}

The COVID-19 (“coronavirus disease 2019”) pandemic caused by the new coronavirus (Sars-CoV-2; severe acute respiratory syndrome corona 2 ) unveils a new preventive reality regarding the prescription of steroid hormones, involving not only the use of combined hormonal contraception(CHC) during the reproductive 
period but also the use of hormone replacement therapy in menopausal transition and post- menopause (MHT). This alert stems from the observation that symptomatic carriers of COVID-19, particularly in its more severe presentation, present hyperactivation of coagulation, which, in combination with the estrogen contained in these formulations, potentially increases the likelihood of thromboembolic ${ }^{1}$ events. In addition to the coronavirus, the fact that patients remain bedridden for long periods also can increase the risk of developing deep vein thrombosis (DVT) and pulmonary thromboembolism (PTE), and the association of multiple risk factors can aggravate this risk ${ }^{2}$.

Sars-CoV-2 is an enveloped virus composed of structural proteins, with emphasis on the Spike glycoprotein (S), the membrane $(M)$, the nucleocapsid $(\mathrm{N})$, and the envelope protein $(E)$. The protein, after entering the host cell, connects to the receiver of the angiotensin-converting enzyme (ACE2) and, with the aid of local endosomal proteases, triggers the fusion of the membrane to the virus endosome, and the viral genome is released. As a result, there is an increase in neutrophils and serum leukocytes, a reduction in the lymphocytes CD4+ and CD 8+, and of regulatory (Tregs), memory, and natural killer (NK) T-cells, and B cells.

In more severe stages of COVID-19, there is a true pro-inflammatory "storm", with the excessive and uncontrolled release of cytokines, which evolves with systemic inflammation, endothelial injury, and exposure of thrombogenic structures (collagen, tissue factor, and platelet adhesion molecules), which favors the formation of thrombi ${ }^{4}$.

In fact, anatomopathological studies show a probable hypercoagulable and immunethrombotic state due to the unveiling of multiple microthrombi in the pulmonary vasculature ${ }^{6}$, thus constituting systemic microangiopathy, which explains the failure of multiple organs (cardiomyopathy, kidney failure, acute liver failure, mesenteric ischemia, and neurological damage). In addition, it should be emphasized that since the vascular endothelium actively expresses ACE2, it becomes an active locale for the multiplication of Sars$\mathrm{CoV}-2$, as had been previously described for patients with Sars-CoV-1 infections ${ }^{7}$.

An alert that should be considered is that coagulation hyperactivation in symptomatic COVID-19 patients with more severe presentations can have an increased risk of thromboembolism when in use of estrogens (CHC and MHT).

\section{METHODS}

Our study is a narrative review of the literature available on the coronavirus so far, focusing on its physiopathology, the stages of the disease, and the occurrence of thrombotic events, as well as on the risk of venous thromboembolism (VTE) in CHC and MHT users, aiming to gather information for a safe approach in women with suspected or confirmed COVID-19. For the review, we searched the Medline/PubMed database using specific keywords ("COVID-19”; "coronavírus”; "contraception"; "menopausal hormone therapy”; "thromboembolic disease"). There were no restrictions regarding date or language. Most data on COVID19 comes from Asia. The electronic databases were searched for the last time on 18 May 2020.

\section{Thromboembolic risk in the COVID-19 pan-} demic

The Spanish Societies of Menopause, Gynecology, and Obstetrics and the Thrombosis and Hemostasis Society recently published recommendations on the use of combined oral hormonal contraceptives (COHC) and menopause hormonal therapy (MHT) in women in menopausal transition with suspected or confirmed COVID-19, based on the severity of the disease.

In these recommendations, the authors suggest that in women with mild symptoms of COVID-19, who do not exhibit risk factors of greater severity, the use of MHT and CHC may be maintained, provided it is associated with low molecular weight heparin (LMWH), in prophylactic doses; when the use of transdermal MHT is preferred, the recommendation is for maintaining the combined hormonal contraception (CHC) or replacing it for methods with progestogen alone. In women with COVID-19 who develop pneumonia, persistent respiratory symptoms, and have more severe risk factors, and in severe cases, it is recommended to suspend the use of MHT and CHC and associate LMWH in therapeutic doses ${ }^{8}$.

It is important that healthcare professionals who guide the use of these hormones know the stages of SARS-CoV-2 infections for an adequate and safe prescription.

A classification of COVID-19 infection severity was proposed by Siddiqi \& Mehra (2020) and is characterized by three stages that correlate signs/symptoms, treatment response, and clinical outcomes ${ }^{9}$.

There is an initial stage of lesser severity, but that can evolve to an excessive inflammatory response, which characterizes the stage of greater severity 
and a worse prognosis (stage III), in which there is a greater production of cytokines and coagulation factors that result in hyperactivation of coagulation, particularly in symptomatic women². In these women, the association of CHC or MHT can increase the risk of thromboembolism.

The risk of VTE is rare in healthy women of reproductive age (5-10 events per 10,000 women yearly), an incidence that increases to 8-10 events per 10,000 women yearly with the use of CHC, a much lower incidence than the risks of VTE observed during pregnancy and the postpartum period ${ }^{10}$. The risk of VTE is associated with the dose of estrogen and the type of progestogen ${ }^{11}$.

The CHC, in addition to promoting increased procoagulant factors (fibrinogen, prothrombin, factors VII, VIII, IX, X, XII), reduces the synthesis of the procoagulant factor $\mathrm{V}$ and inhibitors of hemostasis that occur naturally, such as antithrombin, protein S, and the tissue factor pathway inhibitor (TFPI), which results in an increased risk of thrombosis ${ }^{12}$.

The physiopathological mechanism of hypercoagulability in CHC users occurs by the passage of estrogen through the liver. This prothrombotic effect also occurs with other routes of administration (transdermal, vaginal). Observational studies show that the risk of VTE in users of vaginal rings and transdermal adhesives is, in general, similar to that of users of combined oral hormonal contraception (COHC $)^{13}$.

The type of progestogen used associated with ethinylestradiol can modulate these changes. However, when used in isolation, progestogen does not modify the hemostatic system ${ }^{10}$. COHC containing cyproterone, drospirenone, gestodene, and desogestrel present a relative risk (RR) of 3-4 in relation

FIGURA 1. RECOMMENDATIONS FOR THE MANAGEMENT OF CHC IN WOMEN WITH SUSPECTED OR CONFIRMED COVID-19

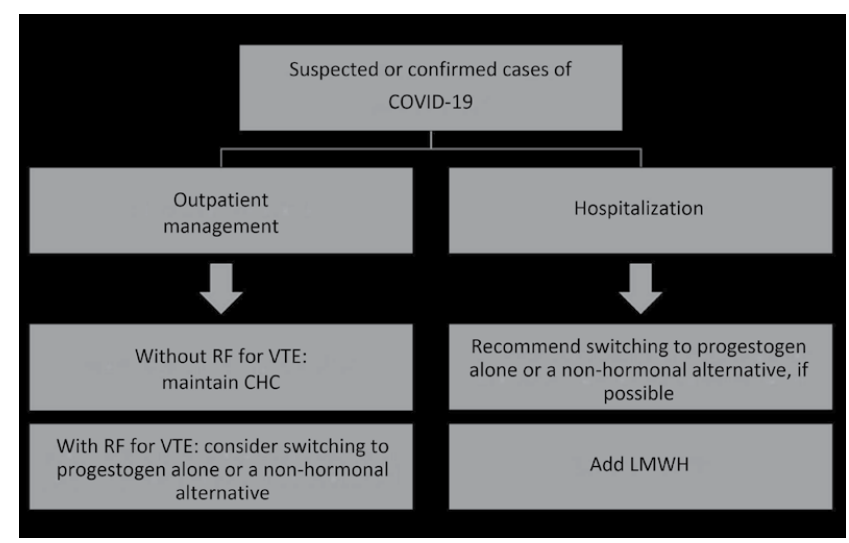

to non-CHC users, while COHC containing levonorgestrel have a RR around 2 in relation to nonCHC users ${ }^{14}$.

The use of contraceptive methods that contain only progestogens (oral, IUD, and implants) is not associated with an increased risk of $\mathrm{VTE}^{14}$.

With respect to MHT, an increased risk two to three times greater has been noted when using the oral route; however, it differs for the transdermal route, which does not seem to increase the risk ${ }^{15}$. A French multicenter case-control study showed that oral estrogen, but not transdermal, is associated with an increased chance of $\mathrm{VTE}^{16}$.

Recommendation for the management of women in use contraceptives and under menopause hormone therapy

It is recommended that, for users of MHT or CHC who suffer from mild cases of COVID-19 and wish to maintain the use of hormones, is it possible to do so, and, based on the risk factors for VTE, the prophylactic use of heparin must be suggested. However, the use of low molecular weight heparin (LMWH) should not be done indiscriminately, but under medical supervision, aiming to reduce the risk of VTE. In addition, in COVID-19 patients with mild symptoms and without severe risk factors it is also wise to replace CHC by contraception containing progestogen alone. Regarding MHT, when oral, it is recommended to be replaced by transdermal (Figures 1 and 2).

Women who change or suspend MHT and contraception must be instructed to undergo an early revaluation, which can be done by telemedicine or in person after the end of the pandemic. Easy access to communication channels to notify about adverse events

FIGURE 2. RECOMMENDATIONS FOR THE MANAGEMENT OF MHT IN WOMEN WITH SUSPECTED OR CONFIRMED COVID-19

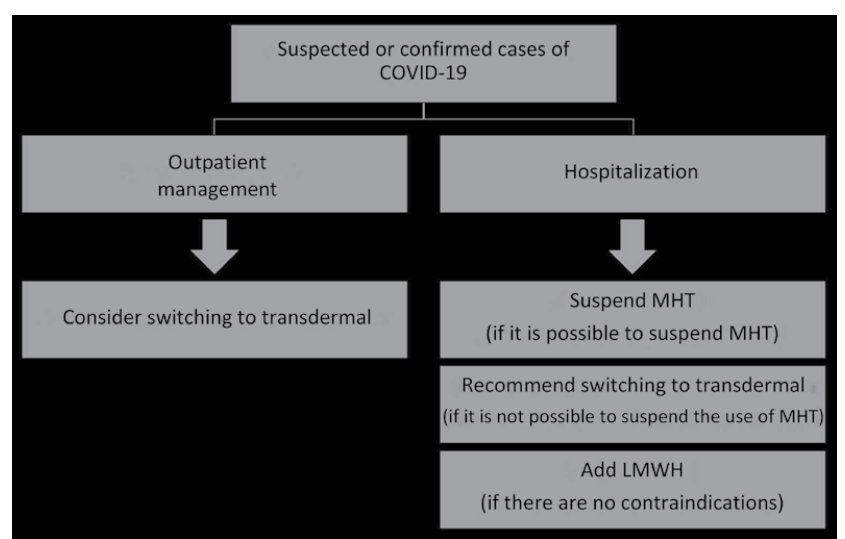


and obtain answers to questions increases women's adaptation to the new method.

\section{Study limitations}

Our study has some limitations since we analyzed different types of studies (observational, experimental, reviews, clinical trials); however, the information is consistent between them and have biological plausibility. Moreover, this is a narrative review, which means it does not conform to the technical principles of a systematic review and can confer it some selection bias; however, the search was conducted in a systematic manner to amplify the number of articles included and minimize this risk. These recommendations will probably be reviewed, after some time, considering the growing number of recent publications in the area; even so, this study is urgent, since it is essential to have national recommendations for the safe management of contraception and menopause hormone therapy.

\section{FINAL CONSIDERATIONS}

Knowledge about the new coronavirus remains limited; however, SARS-CoV-2 infections are gradually being elucidated by the scientific community, thus contributing to the understanding of the pathophysiology of the disease and the risk of VTE.

According to this review, it is important to highlight that users of contraceptives and women under menopause hormone therapy may have a greater risk of thromboembolism, in the duration of the COVID-19 pandemic, and the assessment regarding the maintenance or modification of the prescription should be individualized, considering the severity of the condition and other risk factors for VTE.

\section{RESUMO}

OBJETIVOS: A pandemia da COVID-19 é um problema de saúde pública emergente e que tem repercussão internacional. As alterações inflamatórias fazem parte da fisiopatologia da COVID-19 e isso pode acarretar um maior risco tromboembólico em mulheres que fazem uso de contracepção e terapia hormonal da menopausa. Discutimos os principais aspectos relacionados a esse risco e propomos uma estratégia de seguimento das mulheres acometidas da COVID-19.

MÉTODOS: Esta revisão narrativa coletou informações de vários artigos publicados desde o início da pandemia do novo coronavírus, no que tange à sua fisiopatologia, estágios da doença e ocorrência de eventos trombóticos, bem como sobre o risco de tromboembolismo venoso em usuárias de contracepção e terapia hormonal da menopausa.

RESULTADOS: Este artigo consolida alguns parâmetros clínicos sobre o risco de tromboembolismo em usuárias de contracepção e terapia hormonal na menopausa, enfatizando o provável aumento desse risco em mulheres com suspeita ou confirmação do novo coronavírus, e traz uma recomendação de uma conduta mais segura.

CONCLUSÃo: Nesse cenário, além das fundamentais orientações de medidas preventivas, como o isolamento social e a higiene, é importante que os profissionais que trabalham na atenção à saúde feminina tenham conhecimentos da nova realidade e adotem condutas seguras, especialmente na prescrição de THM e contracepção.

PALAVRAS-CHAVE: Anticoncepção. Terapia de reposição hormonal. Infecções por coronavírus. Betacoronavírus. Tromboembolia venosa/ prevenção e controle.

\section{REFERENCES}

1. Connors JM, Levy JH. Thromboinflammation and the hypercoagulability of COVID-19. J Thromb Haemost. 2020. doi: 10.1111/jth.14849.

2. Anderson FA Jr, Spencer FA. Risk factors for venous thromboembolism. Circulation. 2003;107(23 Suppl 1):19-I16.

3. Tufan A, Avanoğlu Güler A, Matucci-Cerinic M. COVID-19, immune system response, hyperinflammation and repurposing antirheumatic drugs. Turk J Med Sci. 2020;50(SI-1):620-32.

4. Pereira MP, Lima EG, Serrano Junior CV. Viral infections and atherothrombosis: another caution in the wake of COVID-19? Rev Assoc Med Bras. 2020;66(3):366-9.

5. Henry BM, Vikse J, Benoit S, Favaloro EJ, Lippi G. Hyperinflammation and derangement of renin-angiotensin-aldosterone system in COVID-19: a novel hypothesis for clinically suspected hypercoagulopathy and microvascular immunothrombosis. Clin Chim Acta. 2020;507:167-73.
6. Luo W, Yu H, Gou I, Li X, Sun Y, Li I, et al. Clinical pathology of critical patient with novel coronavirus pneumonia (COVID-19). Preprints. 2020; 2020020407.

7. Nicin L, Abplanalp WT, Mellentin H, Kattih B, Tombor L, John D, et al. Cell type-specific expression of the putative SARS-CoV-2 receptor ACE2 in human hearts. Eur Heart J. 2020;41(19):1804-6.

8. Ramírez I, De la Viuda E, Baquedano L, Coronado P, Llaneza P, Mendoza N, et al. Managing thromboembolic risk with menopausal hormone therapy and hormonal contraception in the COVID-19 pandemic: recommendations from the Spanish Menopause Society, Sociedad Española de Ginecología y Obstetricia and Sociedad Española de Trombosis y Hemostasia. Maturitas. 2020;137:57-62. 
9. Siddiai HK, Mehra MR. COVID-19 illness in native and immunosuppressed states: a clinical-therapeutic staging proposal. J Heart Lung Transplantat. 2020;39(5):405-7.

10. Bastos M, Stegeman BH, Rosendaal FR, Van Hylckama Vlieg A, Helmerhorst FM, Stijnen T. Combined oral contraceptives: venous thrombosis. Cochrane Database Syst Rev. 2014;(3):CD10813.

11. Dragoman MV, Tepper NK, Fu R, Curtis KM, Chou R, Gaffield ME. A systematic review and meta-analysis of venous thrombosis risk among users of combined oral contraception. Int | Gynaecol Obstet. 2018;141(3):287-94.

12. Black A, Guilbert E, Costescu D, Dunn S, Fisher W, Kives S. No. 329-Canadian Contraception Consensus Part 4 of 4 Chapter 9: combined hormonal contraception. | Obstet Gynaecol Can. 2017;39(4):229-68.
13. Tepper NK, Whiteman MK, Marchbanks PA, James AH, Curtis KM. Progestin-only contraception and thromboembolism: a systematic review. Contraception. 2016;94(6):678-700.

14. Mantha S, Karp R, Raghavan V, Terrin N, Bauer KA, Zwicker JI. Assessing the risk of venous thromboembolic events in women taking progestin-only contraception: a meta-analysis. BMJ. 2012;345:e4944.

15. Pinkerton JV, James AH. Management of menopausal symptoms for women who are at high risk of thrombosis. Clin Obstet Gynecol. 2018;61(2):260-8

16. Canonico M, Oger E, Plu-Bureau G, Conard I, Meyer G, Lévesque H, et al; Estrogen and Thromboembolism Risk (ESTHER) Study Group. Hormone therapy and venous thromboembolism among postmenopausal women: impact of the route of estrogen administration and progestogens: the ESTHER Study. Circulation. 2007;115(7):840-5. 